\title{
Expression of Eotaxin by Human Lung Epithelial Cells Induction by Cytokines and Inhibition by Glucocorticoids
}

\author{
Craig M. Lilly, ${ }^{*}$ Hidetoshi Nakamura, ${ }^{*}$ Howard Kesselman, ${ }^{\ddagger}$ Cathryn Nagler-Anderson, Koichiro Asano, ${ }^{\star}$ \\ Eduardo A. Garcia-Zepeda, ${ }^{\ddagger}$ Marc E. Rothenberg, ${ }^{\ddagger}$ Jeffery M. Drazen, ${ }^{\star}$ and Andrew D. Luster ${ }^{\ddagger}$ \\ *Combined Program in Pulmonary and Critical Care Medicine, Department of Medicine, Brigham and Women's Hospital and Harvard \\ Medical School, Boston, Massachusetts 02115; ${ }^{\ddagger}$ Infectious Disease Unit, and ${ }^{\S}$ Mucosal Immunology Laboratory, Massachusetts General \\ Hospital and Harvard Medical School, Charlestown, Massachusetts 02129
}

\begin{abstract}
Eotaxin is a potent and specific eosinophil chemoattractant that is mobilized in the respiratory epithelium after allergic stimulation. Pulmonary levels of eotaxin mRNA are known to increase after allergen exposure in sensitized animals. In this study we demonstrate that TNF $\alpha$ and IL-1 $\beta$ induce the accumulation of eotaxin mRNA in the pulmonary epithelial cell lines A549 and BEAS 2B in a dose-dependent manner. Cytokine-induced A549 cell mRNA accumulation was maximal at $4 \mathrm{~h}$ and was significantly enhanced when the cells were costimulated with IFN $\gamma$. TNF $\alpha$ - and IL-1 $\beta$-induced increases in eotaxin mRNA were diminished in a dose-dependent manner by the glucocorticoid dexamethasone and were augmented by the protein synthesis inhibitor cycloheximide. Cytokine-induced increases in eotaxin mRNA expression correlated with increased eotaxin protein production and secretion, and dexamethasone inhibition of cytokine-induced eotaxin mRNA augmentation was associated with diminished eotaxin protein secretion. These findings, together with the known kinetics of TNF $\alpha$ and IL-1 $\beta$ mobilization in asthmatic airways and the potent eosinophil chemotactic effects of eotaxin, define a mechanism linking inflammatory cytokine mobilization to eosinophil recruitment that may be relevant to the pathogenesis of asthma. (J. Clin. Invest. 1997. 99:1767-1773.) Key words: chemokine - eosinophil • cytokine $\bullet$ asthma $\bullet$ allergic disease
\end{abstract}

\section{Introduction}

The role of inflammation in asthma and other allergic diseases of the airways is widely appreciated, and airway inflammation is now included as a defining feature of asthma $(1,2)$. The importance of the presence of eosinophils in the airways of patients with fatal asthma has long been recognized (3), but the mechanisms by which these cells are recruited and retained in

\footnotetext{
Address reprint requests to Craig M. Lilly, Combined Program in Pulmonary and Critical Care Medicine, Department of Medicine, Brigham and Women's Hospital, 75 Francis St., Boston, MA 02115. Phone: 617-278-0714; FAX: 617-232-4623; E-mail: cmlilly@bics.bwh. harvard.edu or Andrew D. Luster, Phone: 617-726-5710; FAX: 617726-5411; E-mail: luster@helix.mgh.harvard.edu

Received for publication 10 April 1996 and accepted in revised form 15 January 1997.
}

J. Clin. Invest.

(C) The American Society for Clinical Investigation, Inc. 0021-9738/97/04/1767/07 \$2.00

Volume 99, Number 7, April 1997, 1767-1773 the lung are only now being elucidated. The importance of airway eosinophilia in less severe forms of asthma has been documented by studies demonstrating eosinophils in the airways of patients with mild asthma (4-6). These findings and the results of other studies linking eosinophil-derived granular proteins (3), arginine-rich proteins, metalloendopeptidases, and lipid metabolites to airway hyperresponsiveness support the ability of appropriately activated eosinophils to contribute to asthma symptoms. The conclusion that tissue eosinophilia is an important factor in allergic airway disease is based not only on the recognition that eosinophils are present in allergic airways but also on the correlation of the remission of asthma symptoms with the resolution of airway eosinophilia (7-10). These observations suggest that eosinophils may be necessary to the pathogenesis of asthma and make it likely that the mechanisms by which eosinophils are recruited to the airways are relevant to asthma.

An increasing but incomplete body of knowledge defines the mechanisms of eosinophil recruitment, retention, and activation in the airways. Eosinophils respond to a growing list of chemoattractants, including complement factor C5a; plateletactivating factor (PAF); leukotriene $\mathrm{B}_{4}$; IL-2, $-3,-5$, and -16 ; and the chemokines IL-8, macrophage inflammatory protein (MIP) ${ }^{1}-1 \alpha$, monocyte chemoattractant protein (MCP)-2, MCP-3, MCP-4, RANTES, and eotaxin (11). The importance of cytokine mobilization in promoting in vivo airway eosinophil recruitment is demonstrated by the effectiveness of IL-5 antagonists in blocking airway eosinophilia after allergen exposure (12). In addition, IL-5-deficient mice do not develop airway eosinophilia, lung damage, or airway hyperreactivity, all of which follow aeroallergen challenge of normal mice (13). The relevance of eosinophil recruitment to asthma is further suggested by studies in which IL-5-neutralizing monoclonal antibodies administered during the period of sensitization prevent the development of airway eosinophilia and hyperreactivity in rodents and primates (14).

Eotaxin is a CC (double cysteine) chemokine that was originally isolated as the predominant eosinophil chemoattractant in the lung lavage fluid of sensitized guinea pigs after allergic exposure (15). Eotaxin is unique among eosinophil-active chemoattractants in that it specifically attracts eosinophils. This specificity has recently been demonstrated in vitro for both mouse (16-18) and human $(19,20)$ eotaxin in chemotaxis and calcium flux assays. The in vivo potency and specificity of eotaxin have been confirmed in studies demonstrating tissue eosinophil recruitment following instillation of this chemokine

1. Abbreviations used in this paper: GAPDH, glyceraldehyde-3-phosphate dehydrogenase; MCP, monocyte chemoattractant protein; MIP, macrophage inflammatory protein. 
into the airways of rodents $(17,18,21)$, and following its injection into the skin of rodents $(15,17)$ and rhesus monkeys $(20)$. Eotaxin is thought to be important in recruiting eosinophils to the airway after allergic stimulation because the time course of its appearance is congruent with that of eosinophil recruitment $(15,18,21,22)$. Although eotaxin can be produced by several cell types, production in airway epithelial cells may be particularly relevant to allergic diseases, as eotaxin immunoreactivity is detectable in the epithelial cells of nasal polyps that are infiltrated with eosinophils (20). It is increasingly clear that the airway epithelium participates in the inflammatory process by altering its phenotype to produce a variety of mediators and cytokines, including prostaglandins (23), platelet-activating factor (24), granulocyte-macrophage colony-stimulating factor (GM-CSF) (25), IL-6 (26), IL-8 (27), MCP-1 (28), and RANTES (29). On the basis of these observations and the known upregulation of eotaxin after allergic pulmonary stimulation, we sought to define the allergic mediators that modulate the expression of eotaxin mRNA, eotaxin protein production, and eotaxin secretion in pulmonary epithelial cells.

\section{Methods}

\section{Cell culture}

A549 cells, derived from a lung adenocarcinoma with the alveolar type II cell phenotype, were obtained from American Type Culture Collection (Rockville, MD). The cells were cultured in F12K medium with $10 \%$ heat-inactivated FBS. $24 \mathrm{~h}$ before stimulation with cytokines, this medium was exchanged for an identical formulation not containing FBS. BEAS 2B cells, a human bronchial epithelial cell line transformed by hybrid adenovirus SV-40, were cultured in DMEMF12 with $10 \%$ FBS. Epithelial cells grown to confluence were stimulated with geometrically increasing doses of IL- $1 \beta, \mathrm{TNF} \alpha$, and IFN $\gamma$, or with $10 \mathrm{nM}$ phorbol PMA, TGF $\alpha, 10 \mathrm{ng} / \mathrm{ml}$, or TGF $\beta(5 \mathrm{ng} / \mathrm{ml})$. In experiments involving dexamethasone or cycloheximide, the agents were added 30 min before cell stimulation. In time course experiments, the cells were harvested $1,2,4,8,16,24,32$, and $48 \mathrm{~h}$ after stimulation. In concentration-response studies, the cells were harvested at the time of peak expression, which was $4 \mathrm{~h}$ after stimulation with IL- $1 \beta$ or TNF $\alpha$ and $2 \mathrm{~h}$ after stimulation with IFN $\gamma$. Protein synthesis was inhibited by the addition of cycloheximide $(10 \mu \mathrm{g} / \mathrm{ml})$ to the medium. This concentration of cycloheximide inhibited $\left[{ }^{35} \mathrm{~S}\right] \mathrm{me}-$ thionine incorporation into trichloroacetic acid-precipitable protein by $>90 \%$.

\section{RNA analysis}

Total RNA was isolated from freshly harvested cells by guanidiniumthiocyanate-phenol chloroform extraction (Stratagene Inc., La Jolla, CA). For Northern analysis, 10-20 $\mu \mathrm{g}$ of total RNA was subjected to gel electrophoresis on a formaldehyde- $2 \%$ agarose gel and transferred to a nylon membrane (Schleicher \& Schuell Inc., Keene, NH). After UV cross-linking, the membrane was hybridized at $42^{\circ} \mathrm{C}$ in a $50 \%$ formamide buffer ( $\mathrm{pH} 7.5$ ), containing $10 \%$ dextran sulfate, $5 \times$ SSC, $1 \times$ Denhardt's solution, $1 \%$ (wt/vol) SDS, $100 \mu \mathrm{g}$ of herring sperm DNA $/ \mathrm{ml}$, and $20 \mathrm{mM}$ Tris either with a ${ }^{32} \mathrm{P}$-labeled 1.1-kb HindIII fragment of the human eotaxin gene containing exon 2 and the coding portion of exon 3-with a PCR-generated fragment whose sequence was confirmed to be identical to that reported for human RANTES cDNA - or with a glyceraldehyde-3-phosphate dehydrogenase (GAPDH) cDNA probe (Clontech, Palo Alto, CA). The membranes were washed for $40 \mathrm{~min}$ at $42^{\circ} \mathrm{C}$ in $2 \times$ SSC $-0.1 \%$ SDS and then for $40 \mathrm{~min}$ at $55^{\circ} \mathrm{C}$ in $0.2 \times \mathrm{SSC}-0.1 \%$ SDS. To control for RNA loading, the hybridization signal obtained for eotaxin was normalized to that of GAPDH for each sample. RNA expression was determined by densitometry as previously reported (22). All experiments involv- ing the quantitation of RNA were performed at least in triplicate and a representative blot is displayed.

\section{Detection of eotaxin protein}

Generation of antieotaxin antibodies. BALB/c mice (Taconic Farms, Germantown, NY) and New Zealand White rabbits (Pocono Rabbit Farm and Laboratory, Canadensis, PA) were immunized with recombinant human eotaxin protein (PeproTech, Rocky Hill, NJ). Spleen cells from immunized mice were fused to the P3X63 hybridoma cell line, and monoclonal antibodies were prepared according to standard techniques. Immune rabbit serum was purified by protein A-Sepharose (Pharmacia, Piscataway, NJ) affinity chromatography according to the manufacturer's specifications. Immunoblot or ELISA analysis of the antieotaxin monoclonal antibody 2A12 and polyclonal antiserum demonstrated that these antibodies were specific for human eotaxin. These antibodies reacted strongly to $100 \mathrm{ng}$ of human eotaxin but did not react to $100 \mathrm{ng}$ of human MCP-1, 2, 3, 4, MIP- $1 \alpha$, MIP-1 $\beta$, or RANTES.
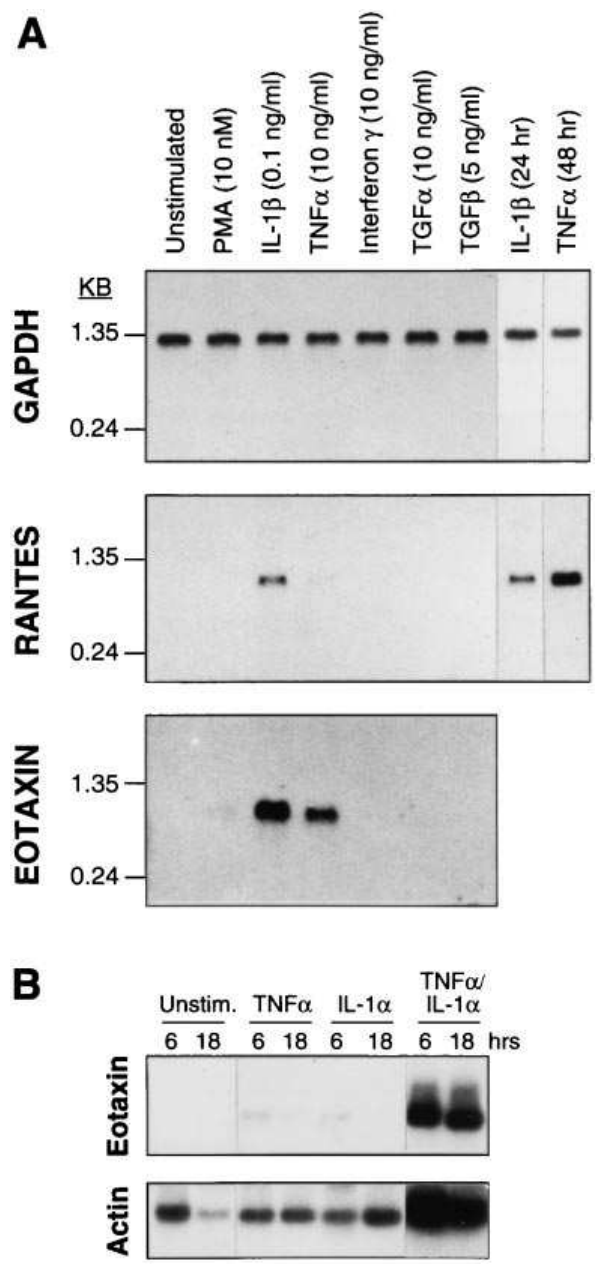

Figure 1. Eotaxin mRNA expression in cytokine treated airway epithelial cells. (A) Northern blot analysis of $20 \mu \mathrm{g}$ total RNA isolated from untreated A549 cells or $4 \mathrm{~h}$ after stimulation with the indicated cytokines. Molecular size markers appear on the left of each blot. The blots were hybridizied sequentially with eotaxin-, RANTES-, and GAPDH-specific gene probes. $(B)$ Northern blot analysis of $10 \mu \mathrm{g}$ total RNA isolated from untreated BEAS $2 \mathrm{~B}$ cells 6 or $18 \mathrm{~h}$ after stimulation with $10 \mathrm{ng} / \mathrm{ml} \mathrm{TNF} \alpha, 5 \mathrm{ng} / \mathrm{ml} \mathrm{IL-} 1 \alpha$, or both. The blots were hybridized sequentially with eotaxin, and GAPDH-specific gene probes. 
ELISA. Each well of a high-binding efficiency 96-well ELISA plate was coated with $100 \mathrm{ng}$ of a mouse antieotaxin monoclonal antibody, designated 2A12. The plate was blocked with a $3 \%$ solution of BSA (Sigma Chemical Co., St. Louis, MO) in PBS with $0.02 \%$ sodium azide. After washing with PBS, standards or sample were added; the plate was incubated $2 \mathrm{~h}$ at room temperature in a humid environment and was washed again with PBS, and $1 \mu \mathrm{g}$ of a protein A-purified fraction of a rabbit antieotaxin polyclonal serum was added to each well. The plates were washed twice with PBS after a 2-h room temperature incubation; $50 \mu \mathrm{l}$ of a horseradish peroxidase-linked antirabbit IgG derived from goats (Kirkegaard \& Perry Laboratories, Inc., Gaithersburg, MD) was diluted 1:1000 in blocking buffer and added to each well. After a 90-min room-temperature incubation, the plates were developed by the 3, 3', 5, 5'-tetramethylbenzidine microwell-peroxidase substrate method according to the instructions of the manufacturer (Kirkegaard \& Perry Laboratories, Inc.). Under these conditions this assay was sensitive to $50 \mathrm{pg} / \mathrm{ml}$. Cell supernatant was harvested from $10^{7}$ cells cultured in the absence of stimulation or $2,4,8,24$, or $48 \mathrm{~h}$ after stimulation with IL-1 $\beta$; the amount of eotaxin recovered was calculated from the ELISA concentration and volume of supernatant and expressed as the amount recovered per $10^{6}$ cells. Cells corresponding to the supernatant samples described above were lysed into $0.5 \mathrm{ml} \mathrm{NP}-40$ lysis buffer, and the eotaxin concentration was determined by ELISA and reported as the amount recovered per $10^{6}$ cells.
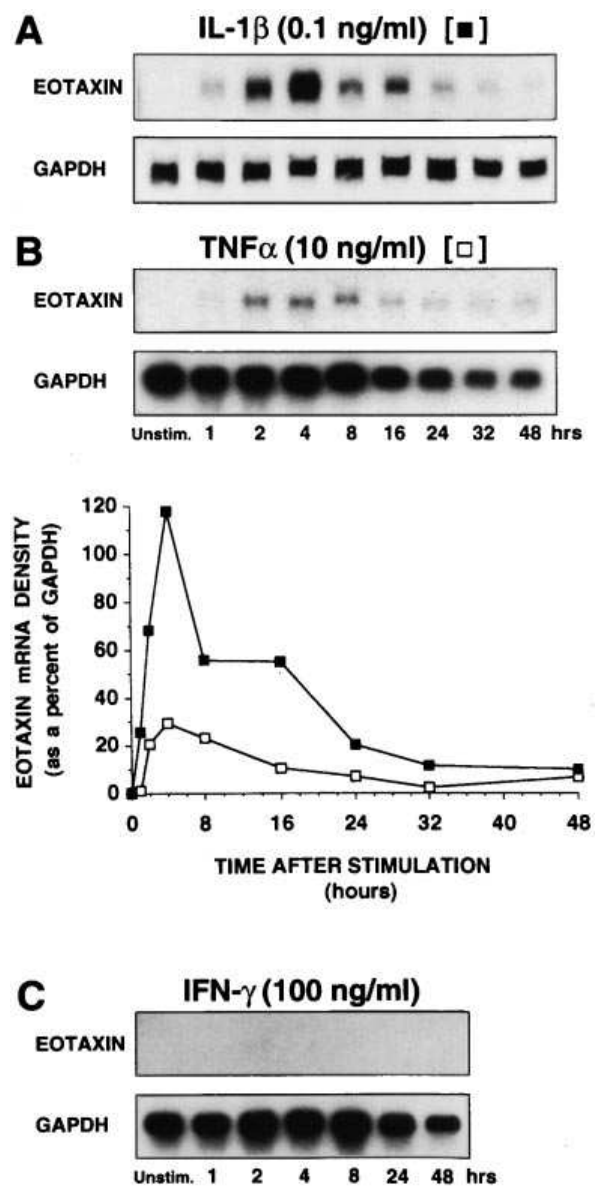

Figure 2. Time course of cytokine-induced eotaxin mRNA accumulation. Northern analysis of $20 \mu \mathrm{g}$ of total RNA harvested from A549 cells at various times after treatment with $0.1 \mathrm{ng} / \mathrm{ml} \mathrm{IL-1 \beta}(A), 10 \mathrm{ng} /$ $\mathrm{ml} \mathrm{TNF} \alpha(B)$, or $100 \mathrm{ng} / \mathrm{ml} \mathrm{IFN} \gamma(C)$. A quantitative comparison at each time point between the eotaxin-specific signal and the GAPDHspecific signal is illustrated below $A$ and $B$.

\section{Results}

\section{Cytokine-induced eotaxin $m R N A$ expression}

Eotaxin mRNA expression was not easily detected by Northern analysis in A549 or in BEAS 2B cells in the absence of cytokine stimulation. However, stimulation of the cells with $0.1 \mathrm{ng}$ of IL- $1 \beta / \mathrm{ml}$ or $10 \mathrm{ng}$ of TNF $\alpha / \mathrm{ml}$ for $4 \mathrm{~h}$ induced the accumulation of a distinct eotaxin mRNA species of $\sim 800 \mathrm{bp}$ (Fig. $1 \mathrm{~A}$ ). The addition of $10 \mathrm{nM}$ PMA to the medium was associated with a faint but detectable eotaxin mRNA signal. However, eotaxin mRNA was not detected after $4 \mathrm{~h}$ of stimulation with IFN $\gamma(10 \mathrm{ng} / \mathrm{ml}), \mathrm{TGF} \alpha(10 \mathrm{ng} / \mathrm{ml})$, or TGF $\beta$ (5 ng/ $\mathrm{ml})$. Similarly, RANTES expression in A549 cells was detectable $4 \mathrm{~h}$ after cytokine stimulation with $0.1 \mathrm{ng} / \mathrm{ml} \mathrm{IL-1 \beta}$ and after $10 \mathrm{ng} / \mathrm{ml} \mathrm{TNF} \alpha$ (Fig. $1 A$ ). Eotaxin mRNA expression in BEAS 2B cells was detectable after stimulation with $5 \mathrm{ng}$ of IL- $1 \alpha / \mathrm{ml}$ or $10 \mathrm{ng}$ of $\mathrm{TNF} \alpha / \mathrm{ml}$ with a time course similar to that of A549 cells. In BEAS 2B cells a synergystic effect of these cytokines was observed (Fig. $1 B$ ).

\section{Time course}

Treatment of A549 cells with $0.1 \mathrm{ng}$ of IL-1 $\beta / \mathrm{ml}$ or $10 \mathrm{ng}$ of $\mathrm{TNF} \alpha / \mathrm{ml}$ induced maximal eotaxin mRNA expression at $4 \mathrm{~h}$; this activity declined over the subsequent $44 \mathrm{~h}$ (Fig. 2, $A$ and $B)$. When $100 \mathrm{ng}$ of IFN $\gamma / \mathrm{ml}$ was added to the medium, eotaxin mRNA expression was detected as a faint band appearing $2 \mathrm{~h}$ after stimulation (Fig. $2 \mathrm{C}$ ). This is in contrast to RANTES which was maximally induced by IL-1 $\beta 24 \mathrm{~h}$ after stimulation while maximal expression after $\mathrm{TNF}-\alpha$ occurred $48 \mathrm{~h}$ after stimulation (Fig. $1 A$; data not shown).

\section{Concentration response characteristic}

The addition of geometrically increasing doses of IL- $1 \beta$ to the medium $4 \mathrm{~h}$ before harvesting was associated with increasing eotaxin mRNA expression. This effect was maximal at a dose of $1 \mathrm{ng} / \mathrm{ml}$ (Fig. 3 A). Likewise, the addition of increasing con-
A
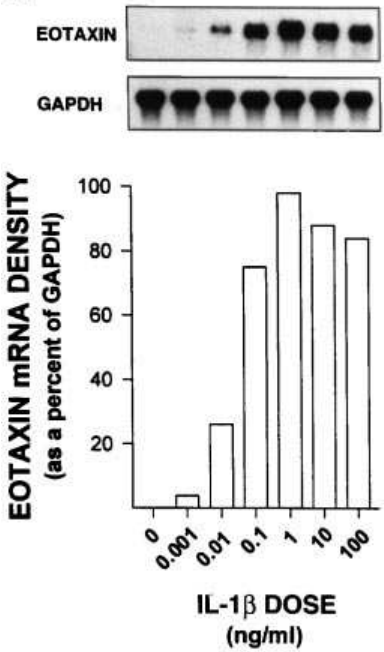

B
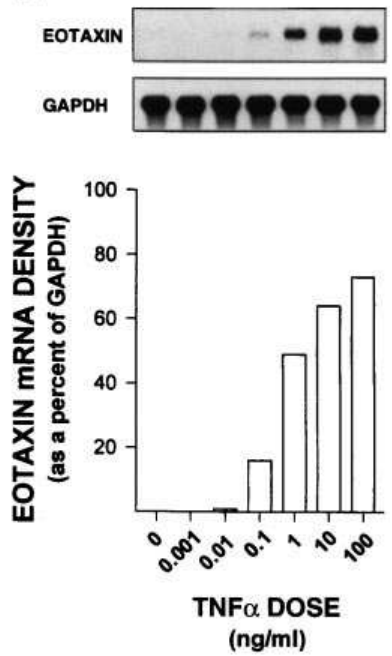

Figure 3. Dose-response of IL-1 $\beta$ - and TNF $\alpha$-induced eotaxin mRNA accumulation. Northern analysis of $20 \mu \mathrm{g}$ of total RNA harvested from A549 cells $4 \mathrm{~h}$ after stimulation with increasing concentrations of IL-1 $\beta(A)$ and TNF $\alpha(B)$. Below each blot a quantitative comparison is made at each dose between the eotaxin-specific signal and the GAPDH-specific signal. 

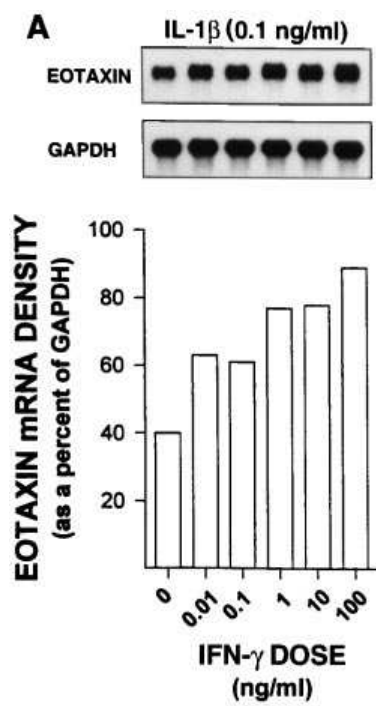

Figure 4. Dose-response characteristics of IFN $\gamma$ synergy. Northern analysis of $20 \mu \mathrm{g}$ of total RNA harvested from A549 cells $4 \mathrm{~h}$ after stimulation with $0.1 \mathrm{ng} / \mathrm{ml} \mathrm{IL-} 1 \beta(A)$ or $10 \mathrm{ng} / \mathrm{ml} \mathrm{TNF} \alpha(B)$ in the presence of increasing concentrations of IFN $\gamma$. Below each blot a quantitative comparison is made at each dose between the eotaxinspecific signal and the GAPDH-specific signal.

centrations of TNF $\alpha$ to the medium up to a dose of $100 \mathrm{ng} / \mathrm{ml}$ was associated with increasing eotaxin mRNA accumulation (Fig. 3 B). Doses of IFN $\gamma$ below $100 \mathrm{ng} / \mathrm{ml}$ produced no signal detectable by Northern analysis (data not shown).

\section{Effects of IFN}

The addition of varying concentrations of IFN $\gamma$ to A549 cells stimulated with $0.1 \mathrm{ng}$ of IL-1 $/ \mathrm{ml}$ increased the expression of eotaxin mRNA in a dose-dependent manner (Fig. $4 \mathrm{~A}$ ); maximal eotaxin expression was increased twofold over that with
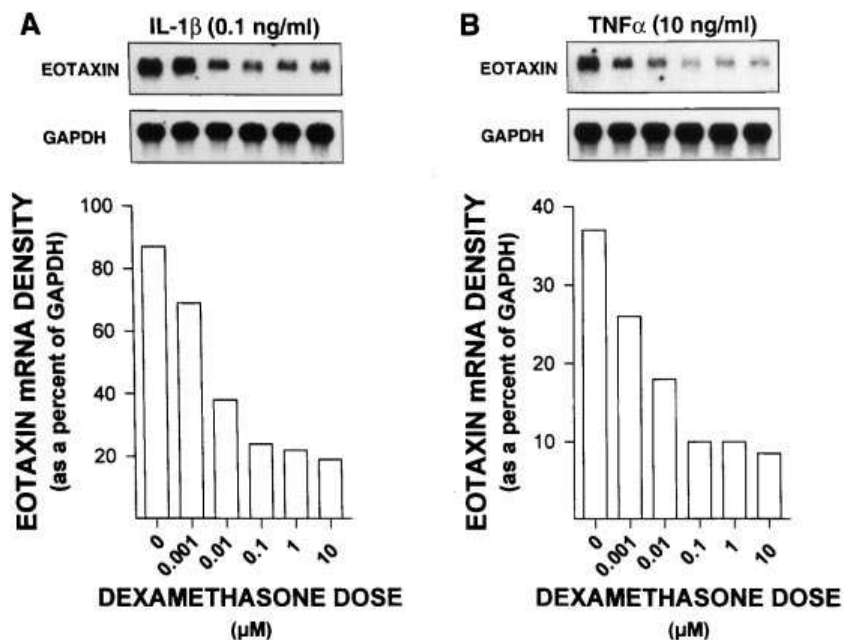

Figure 5. Dose-response characteristics for dexamethasone suppression of cytokine-induced eotaxin mRNA accumulation. Northern analysis of $20 \mu \mathrm{g}$ of total RNA harvested from A549 cells $4 \mathrm{~h}$ after stimulation with $0.1 \mathrm{ng} / \mathrm{ml} \mathrm{IL-1 \beta}(A)$, or $10 \mathrm{ng} / \mathrm{ml} \mathrm{TNF} \alpha(B)$ and increasing concentrations of dexamethasone. Below each blot a quantitative comparison is made at each dose between the eotaxin-specific signal and the GAPDH-specific signal.
IL-1 $\beta$ stimulation alone. Moreover, the addition of increasing doses of IFN $\gamma$ to A549 cells stimulated with $10 \mathrm{ng}$ of TNF $\alpha / \mathrm{ml}$ resulted in a maximal threefold increase in eotaxin mRNA expression over that with TNF $\alpha$ alone (Fig. $4 B$ ). Significant synergistic effects of IFN $\gamma$ were also demonstrated in BEAS $2 \mathrm{~B}$ cells; these effects were maximal at $6 \mathrm{~h}$ and were less apparent $18 \mathrm{~h}$ after stimulation (data not shown).

\section{Effects of dexamethasone}

Pretreatment of A549 cells with varying concentrations of dexamethasone was associated with a dose-dependent decrease in IL-1 $\beta$-induced and TNF $\alpha$-induced eotaxin mRNA expression (Fig. 5, $A$ and $B$ ). The presence of dexamethasone resulted in fourfold and threefold decreases in IL- $1 \beta$-induced and TNF $\alpha$ induced eotaxin mRNA expression, respectively. Dexamethasone treatment had no effect on cell morphology or viability.

Effect of protein-synthesis inhibition on dexamethasone effects When cycloheximide was used to inhibit protein synthesis in A549 cells, eotaxin mRNA was detectable at low levels in the absence of cytokine stimulation (Fig. $6 \mathrm{~A}$ ). Eotaxin mRNA accumulation was superinduced when A549 cells were treated with cycloheximide 30 min before IL-1 $\beta$ stimulation; part of the suppressive effect of dexamethasone persisted in the presence of cycloheximide (Fig. $6 A$ ). TNF $\alpha$-induced eotaxin mRNA expression was likewise enhanced in the presence of cycloheximide and was less inhibited by dexamethasone than IL-1 $\beta$-induced eotaxin mRNA expression (Fig. $6 B$ ).

\section{Eotaxin protein levels}

Time course. Eotaxin protein was detected in the absence of stimulation in both the cell supernatant and the cell lysate. Cell
A
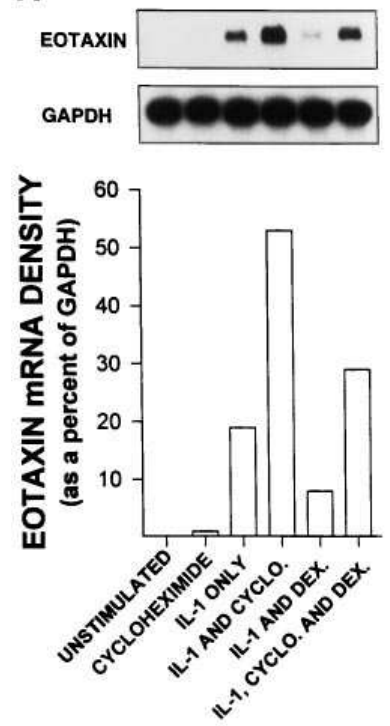

B

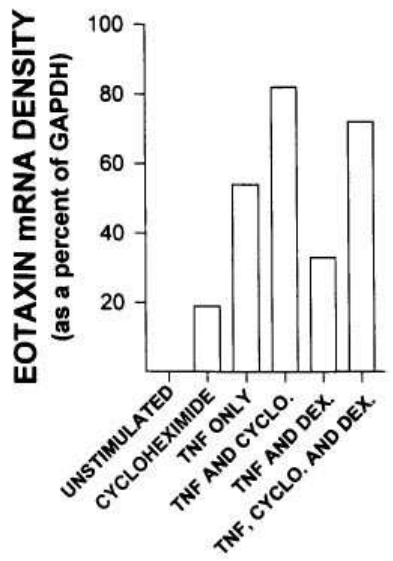

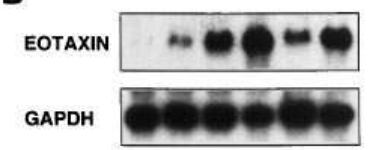

Figure 6. Effects of protein synthesis inhibition on cytokine induction and dexamethasone suppression of eotaxin mRNA accumulation. Northern analysis of $20 \mu \mathrm{g}$ of total RNA harvested from A549 cells $4 \mathrm{~h}$ after the indicated treatments with $0.1 \mathrm{ng} / \mathrm{ml} \mathrm{IL-1 \beta}(A)$ or $10 \mathrm{ng} /$ $\mathrm{ml} \mathrm{TNF} \alpha(B)$. For cells treated with cycloheximide $(10 \mu \mathrm{g} / \mathrm{ml})$ and $/$ or dexamethasone $(1 \mu \mathrm{M})$ plus cytokines, the cycloheximide and dexamethasone were added $30 \mathrm{~min}$ before the addition of the cytokine. Below each blot a quantitative comparison is made with each group between the eotaxin-specific signal and the GAPDH-specific signal. 


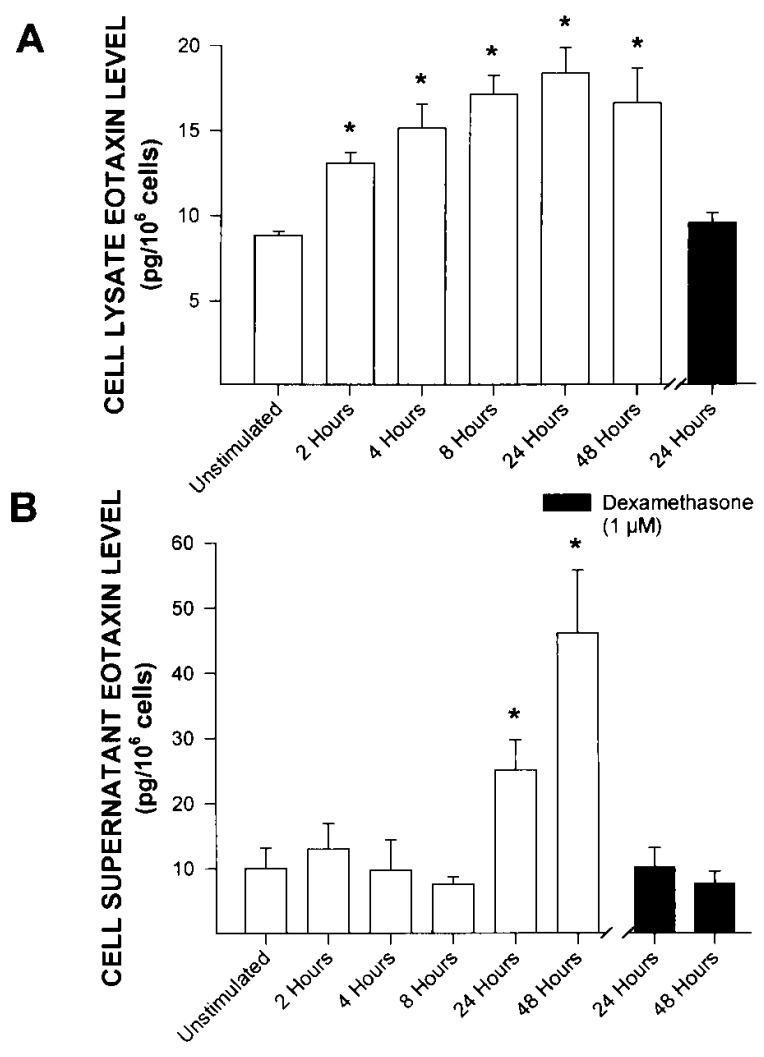

Figure 7. Eotaxin protein levels. $(A)$ Eotaxin protein was measured in A549 cell lysate harvested at the indicated time points after stimulation with $0.1 \mathrm{ng} / \mathrm{ml} \mathrm{IL-} 1 \beta$ in the presence and absence of $1 \mu \mathrm{M}$ dexamethasone $(n=5, * P<0.05)$. (B) Eotaxin protein was measured at the indicated time points following stimulation with $0.1 \mathrm{ng} / \mathrm{ml} \mathrm{IL}-1 \beta$ in A549 cell supernatant in the presence and absence of $1 \mu \mathrm{M}$ dexamethasone $(n=5, * P<0.05)$.

lysate eotaxin protein levels were significantly increased $2 \mathrm{~h}$ after stimulation with $0.1 \mathrm{ng} / \mathrm{ml}$ IL-1 $\beta$. They were significantly elevated at all time points measured, and attained their highest level $24 \mathrm{~h}$ after stimulation (Fig. $7 A ; n=5, P<0.05$, compared with unstimulated cells). Cell supernatant eotaxin levels were elevated $24 \mathrm{~h}$ after stimulation and were increased further at 48 h (Fig. $7 B ; n=5, P<0.05$, compared with unstimulated cells).

\section{Dexamethasone effects}

When $1 \mu \mathrm{M}$ dexamethasone was present in the medium, cell lysate levels of eotaxin in groups of cells stimulated $24 \mathrm{~h}$ earlier with $0.1 \mathrm{ng} / \mathrm{ml} \mathrm{IL-1 \beta}$ were significantly lower than levels in cells not exposed to dexamethasone and were not different from levels in cells that had not been stimulated with IL-1 $\beta$ $(n=5, P<0.05)$. Similarly, the presence of $1 \mu \mathrm{M}$ dexamethasone resulted in a significant decrease in the level of eotaxin in the supernatant of cytokine-treated cells at both 24 and $48 \mathrm{~h}$ $(n=5, P<0.05)$ compared to cytokine treated cells not exposed to dexamethasone.

\section{Discussion}

This study demonstrates that TNF $\alpha$ and IL- $1 \beta$ rapidly and transiently induce the accumulation of eotaxin mRNA in bronchial epithelial cell lines and that this increase is associated with the intracellular accumulation of eotaxin protein and its secretion into the cell supernatant. These findings, taken together with the known kinetics of TNF $\alpha$ and IL- $1 \beta$ mobilization in asthmatic airways, the kinetics of eosinophil recruitment into human airways after segmental allergen challenge, and the potent eosinophil chemotactic effects of eotaxin, define a mechanism linking cytokine mobilization to eosinophil recruitment that may be relevant to the pathogenesis of asthma.

A growing body of evidence links IL-1 $\beta$ to asthma. Like $\mathrm{TNF} \alpha$, IL-1 $\beta$ is found at increased levels in the lung lavage fluid of patients with asthma, and in situ hybridization studies have implicated airway epithelial cells as well as alveolar macrophages in IL- $1 \beta$ production (30). These cells are known to display surface markers of activation and to produce significant quantities of IL- $1 \beta$ during episodes of nocturnal asthma at a time when eosinophil recruitment correlates with airflow obstruction (31). Histological evaluation of lung biopsy specimens from patients with nocturnal asthma has documented the presence of eosinophils predominantly in distal airway segments, where IL-1 $\beta$ produced by alveolar macrophages are available to epithelial cells (30). Because ciliated epithelial cells are not present in the distal airway epithelium, the alveolar epithelium (as reflected by our findings in alveolar cell lines) may be relevant to eosinophil recruitment. Our finding that IL-1 $\beta$ can act on airway epithelial cells to augment eotaxin mRNA expression, protein production, and secretion supports the hypothesis that IL- $1 \beta$ produced by alveolar macrophages induces airway epithelial cells to produce eotaxin and may explain the association among IL-1 $\beta$, airway eosinophilia, and nocturnal airway narrowing.

The higher levels of eotaxin immunoreactivity in nasal epithelial cells at sites of active allergic inflammation where cytokines including TNF $\alpha$ and IL-1 $\beta$ are known to be available as opposed to adjacent noninflamed, noncytokine-expressing epithelium imply the existence of a mechanism modulating eotaxin production in allergic airway disease that may involve these cytokines (20). We found that eotaxin protein secreted from A549 cells accumulates over 24 to $48 \mathrm{~h}$ in cell supernatant. Because eosinophil recovery from the asthmatic lung is maximal $24-48 \mathrm{~h}$ after segmental allergen challenge $(32,33)$ our findings are compatible with the hypothesis that airway epithelial cell-derived eotaxin contributes to allergen-induced airway eosinophilia.

Although TNF $\alpha$ can cause the characteristic physiological phenotype of asthma, namely airway hyperresponsiveness and eosinophilia, the fact that it is not a potent chemoattractant for eosinophils suggests that its effects on eosinophil recruitment are indirect. Our observation that TNF $\alpha$ significantly enhances eotaxin mRNA expression at $4 \mathrm{~h}(22)$ and the observation that TNF $\alpha$-stimulated A549 cells rapidly mobilize a substance chemotactic for eosinophils (34) are compatible with the notion that TNF $\alpha$ mobilized by allergic stimulation may contribute to eotaxin production and eosinophil recruitment. A549 cells were more sensitive than BEAS 2B cells to TNFo-induced augmentation of eotaxin mRNA, but the responsiveness of both cell types suggests that the eotaxin response to cytokines is not a unique feature of A549 cells. The rapid TNF $\alpha$-induced mobilization of eotaxin mRNA is congruent with the time course of augmented lung eotaxin mRNA expression following allergen challenge in animal models $(15,22)$, while the ac- 
cumulation of RANTES mRNA in these cells occurs over a longer time course (Fig. $1 A$ ). The fact that the time course of RANTES mRNA expression is delayed relative to that of eotaxin implies that they have different roles.

We examined the effects of cycloheximide, given at concentrations sufficient to inhibit protein synthesis in our system, on eotaxin mRNA expression in unstimulated and cytokinestimulated A549 cells. Protein inhibition resulted in the accumulation of eotaxin mRNA in unstimulated cells and augmented the ability of cytokines to increase eotaxin mRNA expression. These findings suggest that a protein of short halflife inhibits the transcription of eotaxin, which constitutes a mechanism by which epithelial cells prevent the expression on eotaxin. Alternatively, this protein may inhibit epithelial cell eotaxin expression by degrading eotaxin mRNA. The plausibility of the latter scenario is supported by the fact that eotaxin mRNA contains AU-rich motifs in its $3^{\prime}$ untranslated region that are believed to be responsible for decreasing mRNA stability and translational efficiency of cytokine and oncoprotein genes $(35,36)$. Our data do not allow us to distinguish between these two possibilities.

The synergistic effects of IFN $\gamma$ on cytokine-induced eotaxin mRNA expression are a mechanism by which IFN $\gamma$ can promote tissue eosinophilia. These findings imply that TNF $\alpha$ or IL-1 $\beta$ can interact with IFN $\gamma$ produced by Th1 cells to mobilize airway epithelial eotaxin and to recruit eosinophils through mechanistic pathways that are independent of Th2 lymphocyte products. Our observations support a proallergic role for IFN $\gamma$ that may be relevant to the airway inflammation and airflow obstruction that follow nonallergic conditions, such as viral infections that are known to induce airway cytokine and IFN $\gamma$ production.

Glucocorticoids are antiinflammatory steroids that cause a decrement in airway eosinophilia, normalization of airway tone, and resolution of asthma symptoms (7-10). Although glucocorticoids are effective for treating asthma, they have significant adverse effects. It is therefore desirable to dissect the mechanisms of glucocorticoid action relevant to their effectiveness in suppressing the inflammation of asthma that could allow the development of more specific and less toxic effective agents. Glucocorticoids can diminish airway eosinophils by several established mechanisms, including the induction of eosinophil apoptosis (37), limitation of the production of eosinophil growth and differentiation factors (38), and alteration of the expression of cytokines $(34,38-41)$. The inhibition of cytokine-induced eotaxin mRNA expression and protein production in A549 cells by the glucocorticoid dexamethasone constitutes a novel eosinophil-specific mechanism by which cytokine-induced airway inflammation is suppressed by glucocorticoids. In order to determine whether glucocorticoids directly suppress eotaxin mRNA expression or whether this effect depends on new protein synthesis, we examined the suppressive effects of dexamethasone in the presence and absence of the protein-synthesis inhibitor cycloheximide. Our finding that dexamethasone exerts part of its suppressive effects in the absence of new protein synthesis is compatible with the hypothesis that glucocorticoids act directly to suppress eotaxin mRNA accumulation. The presence of AU-rich sequences in the $3^{\prime}$ untranslated region of eotaxin mRNA suggests that glucocorticoids may decrease mRNA stability as has been described for IFN $\beta$ (42). That dexamethasone-induced suppression of eotaxin mRNA expression is associated with suppression of eo- taxin protein production and secretion supports the hypothesis that part of the inhibitory effect of glucocorticoids on airway eosinophil presence is due to the inhibition of eotaxin production by airway epithelial cells.

In summary, the proinflammatory cytokines $\mathrm{TNF} \alpha$ and IL-1 $\beta$ induce eotaxin mRNA expression, protein production, and secretion in A549 cells, a pulmonary epithelial cell line. The induction of eotaxin by cytokines that are known to be mobilized in asthma and the time course of this induction are compatible with the hypothesis that cytokines released near distal airways drive epithelial-cell eotaxin production, which should cause eosinophil recruitment. Cytokine-induced eotaxin mRNA expression is enhanced by IFN $\gamma$ and cycloheximide and is suppressed by dexamethasone. The ability of dexamethasone to suppress eotaxin production and secretion in airway epithelial cells defines a novel mechanism of glucocorticoid effect that may be relevant to eosinophilic diseases of the airways. These studies provide a mechanistic link between cytokine mobilization and airway eosinophil recruitment relevant to asthma and support the hypothesis that eotaxin production in airway epithelial cells can be driven by cytokines and suppressed by dexamethasone.

\section{Acknowledgments}

We are grateful for the technical assistance of Paul Alfaro.

This work was supported by National Heart, Lung, and Blood Institute grants HL-03283 (C.M. Lilly) and AI 40618 (A.D. Luster and C.M. Lilly), a National Institute of Health Fogarty International Fellowship (E.A. Garcia-Zepeda), a Cancer Research Institute/Benjamin Jacobsen Family Investigator award (A.D. Luster), a grant from Partners HealthCare System Inc. (C.M. Lilly and A.D. Luster) and a center grant to the Massachusetts General Hospital for the study of inflammatory bowel disease DK-43551 (C. Nagler-Anderson and A.D. Luster).

\section{References}

1. Kay, A.B. 1991. Asthma and inflammation. J. Allergy Clin. Immunol. 87: 893-910.

2. Mcfadden, E.R., and I.A. Gilbert. 1992. Medical progress-asthma. N. Engl. J. Med. 327:1928-1937.

3. Dunnill, M.S. 1960. The pathology of asthma, with special reference to changes in the bronchial mucosa. J. Clin. Pathol. 13:27-33.

4. Beasley, R., W.R. Roche, J.A. Roberts, and S.T. Holgate. 1989. Cellular events in the bronchi in mild asthma and after bronchial provocation. Am. Rev. Respir. Dis. 139:806-817.

5. Laitinen, L.A., M. Heino, A. Laitinen, T. Kava, and T. Haahtela. 1985. Damage of the airway epithelium and bronchial reactivity in patients with asthma. Am. Rev. Respir. Dis. 131:599-606.

6. Bousquet, J., P. Chanez, J.Y. Lacoste, G. Barneon, N. Ghavanian, I Enander, P. Venge, S. Ahlstedt, J. Simony-Lafontaine, P. Godard, et al. 1990. Eosinophilic inflammation in asthma. N. Engl. J. Med. 323:1033-1039.

7. Adelroth, E., L. Rosenhall, S.A. Johansson, M. Linden, and P. Venge. 1990. Inflammatory cells and eosinophilic activity in asthmatics investigated by bronchoalveolar lavage. The effects of antiasthmatic treatment with budesonide or terbutaline. Am. Rev. Respir. Dis. 142:91-99.

8. Burke, C., C.K. Power, A. Norris, A. Condez, B. Schmekel, and L.W. Poulter. 1992. Lung function and immunopathological changes after inhaled corticosteroid therapy in asthma. Eur. Respir. J. 5:73-79.

9. Djukanovic, R., J.W. Wilson, K.M. Britten, S.J. Wilson, A.F. Walls, W.R. Roche, P.H. Howarth, and S.T. Holgate. 1992. Effect of an inhaled corticosteroid on airway inflammation and symptoms in asthma. Am. Rev. Respir. Dis. 145:669-674.

10. Laitinen, L.A., A. Laitinen, and T. Haahtela. 1992. A comparative study of the effects of an inhaled corticosteroid, budesonide, and a beta 2-agonist, terbutaline, on airway inflammation in newly diagnosed asthma: a randomized, double-blind, parallel-group controlled trial. J. Allergy Clin. Immunol. 90:32-42.

11. Resnick, M.B., and P.F. Weller. 1993. Mechanisms of eosinophil recruitment. Am. J. Respir. Cell Mol. Biol. 8:349-355. 
12. Mauser, P.J., A. Pitman, A. Witt, X. Fernandez, J. Zurcher, T. Kung, H. Jones, A.S. Watnick, R.W. Egan, W. Kreutner, et al. 1993. Inhibitory effect of the Trfk-5 anti-IL-5 antibody in a guinea pig model of asthma. Am. Rev. Respir. Dis. 148:1623-1627.

13. Foster, P.S., S.P. Hogan, A.J. Ramsay, K.I. Matthaei, and I.G. Young. 1996. Interleukin 5 deficiency abolishes eosinophilia, airways hyperreactivity, and lung damage in a mouse asthma model. J. Exp. Med. 183:195-201.

14. Mauser, P.J., A.M. Pitman, X. Fernandez, S.K. Foran, G.K. Adams, W. Kreutner, R.W. Egan, and R.W. Chapman. 1995. Effects of an antibody to IL-5 in a monkey model of asthma. Am. J. Respir. Crit. Care Med. 152:467-472.

15. Jose, P.J., D.A. Griffiths-Johnson, P.D. Collins, D.T. Walsh, R. Moqbel, N.F. Totty, O. Truong, J.J. Hsuan, and T.J. Williams. 1994. Eotaxin: a potent eosinophil chemoattractant cytokine detected in a guinea pig model of allergic airways inflammation. J. Exp. Med. 179:881-887.

16. Rothenberg, M.E., A.D. Luster, and P. Leder. 1995. Murine eotaxin: an eosinophil chemoattractant inducible in endothelial cells and in interleukin 4-induced tumor suppression. Proc. Natl. Acad. Sci. USA. 92:8960-8964.

17. Rothenberg, M.E., R. Ownbey, P.D. Melhop, P.M. Loiselle, M. van de Rijn, J.V. Bonventre, H.C. Oettgen, P. Leder, and A.D. Luster. 1996. Eotaxin triggers eosinophil-selective chemotaxis and calcium flux via a distinct receptor and induces pulmonary eosinophilia in the presence of interleukin 5 in mice. Mol. Med. 2:334-348.

18. Gonzalo, J.-A., G.-Q. Jia, V. Aguirre, D. Freind, A.J. Coyle, N.A. Jenkins, G.-S. Lin, H. Katz, A. Lichtman, N. Copeland, et al. 1996. Mouse eotaxin expression parallels eosinophil accumulation during lung allergic inflammation but it is not restricted to a Th2-type response. Immunity. 4:1-14.

19. Garcia-Zepeda, E.A., M.E. Rothenberg, R.T. Ownbey, J. Celestin, P. Leder, and A.D. Luster. 1996. Human eotaxin is an eosinophil selective chemoattractant that provides a new mechanism to explain tissue eosinophilia. Nat. Med. 2:449-456.

20. Ponath, P.D., S. Qin, D.J. Ringler, I. Clark-Lewis, J. Wang, N. Kassam, H. Smith, X. Shi, J.-A. Gonzalo, W. Newman, et al. 1996. Cloning of the human eosinophil chemoattractant, eotaxin. J. Clin. Invest. 97:604-612.

21. Griffiths-Johnson, D.A., P.D. Collins, A.G. Rossi, P.J. Jose, and T.J. Williams. 1993. The chemokine, eotaxin, activates guinea-pig eosinophils in vitro and causes their accumulation into the lung in vivo. Biochem. Biophys. Res. Commun. 197:1167-1172.

22. Rothenberg, M.E., A.D. Luster, C.M. Lilly, J.M. Drazen, and P. Leder. 1995. Constitutive and allergen-induced expression of eotaxin mRNA in the guinea pig lung. J. Exp. Med. 181:1211-1216.

23. Churchill, L., F.H. Chilton, J.H. Resau, R. Bascom, W.C. Hubbard, and D. Proud. 1989. Cyclooxygenase metabolism of endogenous arachidonic acid by cultured human tracheal epithelial cells. Am. Rev. Respir. Dis. 140:449-459.

24. Holtzman, M.J., B. Ferdman, A. Bohrer, and J. Turk. 1991. Synthesis of the 1-O-Hexadecyl molecular species of platelet-activating factor by airway epithelial and vascular endothelial cells. Biochem. Biophys. Res. Commun. 177: 357-364

25. Churchill, L., B. Friedman, R.P. Schleimer, and D. Proud. 1992. Production of granulocyte-macrophage colony-stimulating factor by cultured human tracheal epithelial cells. Immunology. 75:189-195.

26. Marini, M., E. Vittori, J. Hollemborg, and S. Mattoli. 1992. Expression of the potent inflammatory cytokines, granulocyte-macrophage-colony-stimulating factor and interleukin- 6 and interleukin-8, in bronchial epithelial cells of patients with asthma. J. Allergy Clin. Immunol. 89:1001-1009.
27. Kwon, O.J., B.T. Au, P.D. Collins, J.N. Baraniuk, I.M. Adcock, K.F. Chung, and P.J. Barnes. 1994. Inhibition of interleukin-8 expression by dexamethasone in human cultured airway epithelial cells. Immunology. 81:389-394.

28. Sousa, A.R., S.J. Lane, J.A. Nakhosteen, T. Yoshimura, T.H. Lee, and R.N. Poston. 1994. Increased expression of the monocyte chemoattractant protein-1 in bronchial tissue from asthmatic subjects. Am. J. Respir. Cell Mol. Biol. 10:142-147.

29. Stellato, C., L.A. Beck, G.A. Gorgone, D. Proud, T.J. Schall, S.J. Ono, L M. Lichtenstein, and R.P. Schleimer. 1995. Expression of the chemokine RANTES by a human bronchial epithelial cell line. Modulation by cytokines and glucocorticoids. J. Immunol. 155:410-418.

30. Kraft, M., R. Djukanovic, J. Torvik, L. Cunningham, J. Henson, S. Wilson, S.T. Holgate, D. Hyde, and R. Martin. 1995. Evaluation of airway inflammation by endobronchial and transbronchial biopsy in nocturnal and nonnocturnal asthma. Chest. 107(Suppl. 3):162s.

31. Borish, L., J.J. Mascali, J. Dishuck, W.R. Beam, R.J. Martin, and L.J. Rosenwasser. 1992. Detection of alveolar macrophage-derived IL-1 beta in asthma. Inhibition with corticosteroids. J. Immunol. 149:3078-3082.

32. Shaver, J.R., J.J. O'Connor, M. Pollice, S.K. Cho, G.C. Kane, J.E. Fish, and S.P. Peters. 1995. Pulmonary inflammation after segmental ragweed challenge in allergic asthmatic and nonasthmatic subjects. Am. J. Respir. Crit. Care Med. 152:1189-1197.

33. Metzger, W.J., D. Zavala, H.B. Richerson, P. Moseley, P. Iwamota, M. Monick, K. Sjoerdsma, and G.W. Hunninghake. 1987. Local allergen challenge and bronchoalveolar lavage of allergic asthmatic lungs. Description of the model and local airway inflammation. Am. Rev. Respir. Dis. 135:433-440.

34. Kwon, O.J., P.J. Jose, R.A. Robbins, T.J. Schall, T.J. Williams, and P.J. Barnes. 1995. Glucocorticoid inhibition of RANTES expression in human lung epithelial cells. Am. J. Respir. Cell Mol. Biol. 12:488-496.

35. Caput, D., B. Beutler, K. Hartog, R. Thayer, S. Brown-Shimer, and A. Cerami. 1986. Identification of a common nucleotide sequence in the $3^{\prime}$-untranslated region of mRNA molecules specifying inflammatory mediators. Proc. Natl. Acad. Sci. USA. 83:1670-1674.

36. Kruys, V., O. Marinx, G. Shaw, J. Deschamps, and G. Huez. 1989. Translational blockade imposed by cytokine-derived UA-rich sequences. Science (Wash. DC). 245:852-855.

37. Schleimer, R.P., and B.S. Bochner. 1994. The effects of glucocorticoids on human eosinophils. J. Allergy Clin. Immunol. 94:1202-1213.

38. Rolfe, F.G., J.M. Hughes, C.L. Armour, and W.A. Sewell. 1992. Inhibition of interleukin-5 gene expression by dexamethasone. Immunology. 77:494499.

39. Guyre, P.M., M.T. Girard, P.M. Morganelli, and P.D. Manganiello. 1988. Glucocorticoid effects on the production and actions of immune cytokines. J. Steroid Biochem. 30:89-93.

40. Wu, C.Y., C. Fargeas, T. Nakajima, and G. Delespesse. 1991. Glucocorticoids suppress the production of interleukin 4 by human lymphocytes. Eur. J. Immunol. 21:2645-2647.

41. Mukaida, N., M. Morita, Y. Ishikawa, N. Rice, S. Okamoto, T. Kasahara, and K. Matsushima. 1994. Novel mechanism of glucocorticoid-mediated gene repression. Nuclear factor-kappa B is target for glucocorticoid-mediated interleukin 8 gene repression. J. Biol. Chem. 269:13289-13295.

42. Peppel, K., J.M. Vinci, and C. Baglioni. 1991. The AU-rich sequences in the $3^{\prime}$ untranslated region mediate the increased turnover of interferon mRNA induced by glucocorticoids. J. Exp. Med. 173:349-355. 